\title{
Effect of Transglutaminase and Egg White on Functional Properties and Microstructure of Fish Paneer from Tilapia and Common Carp
}

\author{
A. Sarojini ${ }^{1}$, D. Sukumar ${ }^{2}$ and Vikas Kumar ${ }^{3 *}$ \\ ${ }^{1}$ Fisheries College and Research Institute, TNJFU, Parakkai, Tamil Nadu, INDIA \\ ${ }^{2}$ Department of Fish Processing Technology, Fisheries College and Research Institute, TNJFU, Thoothukudi, Tamil Nadu, INDIA \\ ${ }^{3}$ ICAR-Central Institute of Post-Harvest Engineering and Technology, P.O. PAU, Ludhiana, Punjab, INDIA \\ "Corresponding author: V Kumar; E-mail: vikasfpt@gmail.com
}

Received: 12 Oct., 2020

Revised: 14 Dec., 2020

Accepted: 15 Dec., 2020

\begin{abstract}
In this research study a high value restructured surimi gel product fish paneer was developed from the fish mince obtained from commercially low value fishes like tilapia (Oreochromis sp.) and common carp (Cyprinus carpio). The effect of protein additives (transglutaminase and egg white) on functional properties and microstructure of fish paneer was studied. Functional properties such as gel strength (23.7 kgf), water holding capacity $(142 \%)$, expressible moisture content (26\%) were highest in fish paneer prepared with transglutaminase $(0.5 \%)$ added in surimi (tilapia: common carp, $1: 1)$. Folding test also revealed the highest quality of gel prepared from surimi containing transglutaminase. The egg white (1\%) influenced the functional qualities positively but had lesser effectiveness than transglutaminase. The microstructure study using scanning electron microscopy images of fish paneer confirmed better effectiveness of transglutaminase $(0.05 \%)$ in binding the protein molecules than egg white (1\%).

\section{HIGHLIGHTS}

0 Gel prepared from surimi containing transglutaminase had highest quality.

( $)$ Egg white $(1 \%)$ had lesser effectiveness on the functional qualities than transglutaminase $(0.05 \%)$.

( Transglutaminase $(0.05 \%)$ was more effective for microstructure than egg white (1\%).
\end{abstract}

Keywords: Fish Paneer, Transglutaminase, Egg White, Functional Properties, Microstructure

Fish is an important food for several populations because of its nutritional qualities like high quality proteins, vitamins, minerals and lipids, besides a great source of $\omega-3$ PUFA. Global fish production (total 178.5 MT in 2018) was contributed greatly by aquaculture (82.1 MT) nearly half of per capita global fish consumption (20 $\mathrm{kg})(\mathrm{FAO}, 2020)$. India, $2^{\text {nd }}$ largest fish producer in the world also produced $13.42 \mathrm{MT}$ of fish with the largest share from aquaculture (7.77 MT) (2018-19) (NFP, 2020). India earned ₹ 46,662.85 crore (USD 6.68 billion) by export of fishery products $(12,89,651$ MT MT) (FY 201920) (MPEDA, 2020). In the above scenario, effective utilization of cultured fish especially low value fresh water fish like tilapia and common carp find importance and thereby the development of value-added fish products like mince, surimi (Japanese term for ground fish paste) and restructured surimi gel products becomes good options. Similar to milk paneer fish paneer is one of the restructured surimi gel product.

Today, surimi products are popular food item not only in Japan but also in many other countries due to its unique

How to cite this article: Sarojini, A., Sukumar, D. and Kumar, V. (2020) Effect of transglutaminase and egg white on functional properties and microstructure of fish paneer from tilapia and common carp. J. Anim. Res., 10(6): 931-940.

Source of Support: None; Conflict of Interest: None क क 
textural properties and high nutritional value (Park and Morrissey, 2000). It is produced by repeatedly washing of mechanically separated fish flesh with chilled water (5-10 ${ }^{\circ} \mathrm{C}$ ) until most of the water soluble protein and fats are removed and then by following established steps in surimi technology (Rawdkuen et al. 2009). Alaska Pollack is the most commonly used lean fish in surimi industry. The other fishes used for surimi processing include cod, herring, whiting, mackerel, sardine, anchovy and goby, etc. (Lee, 1984). Freshwater fishes are excellent sources of high quality protein because they contain highly digestible and well balanced essential amino acids (Karmas and Lauber, 1987). The freshwater fishes like carps, tilapia, and mullet are good for surimi production (Gopakumar, 1997).

Surimi is used in the formulation of various food products ranging from traditional products of Japan such as chikuwa, kamaboko and hampen, to seafood analogs (Thanachan, 2008). Surimi based gel products represent the most suitable food application for underutilized fish species (Worawan et al., 2010). In order to improve the mechanical and functional properties of restructured fish surimi gel products several protein additives have been reported: egg white, casein, transglutaminase, beef plasma thrombin and whey protein concentrate (Ramirez et al., 2006). Egg white is used to increase gel strength. It also gives a whiter and glossier appearance to the gel (Park, 2000). Transglutaminase is used in food industry for setting of surimi (Kuraishi et al., 2001). Therefore, the present study was undertaken to develop a novel restructured surimi gel product fish paneer and to study the effects of transglutaminase and egg white on the functional properties (gel strength, gel quality, water holding capacity and emulsifying capacity) and microstructure of fish paneer.

\section{MATERIALS AND METHODS}

\section{Procurement of fishes and their dressing}

Two very common low value fishes tilapia (Oreochromis $\mathrm{sp}$ ) and common carp (Cyprinus carpio) were procured from Authoor market, Thoothukudi District (Tamil Nadu) to the shore laboratory of Fish Processing Technology Department, FC\&RI, TNJFU, Tuticorin, T.N. within 3 hours in chilled condition in an insulated container with fish to ice ratio of 1: 1 . The average length and weight of tilapia $(27 \pm 1.5 \mathrm{~cm}$ and $327 \pm 5.7 \mathrm{~g})$ and common carp $(50 \pm 1.9 \mathrm{~cm}$ and $1572 \pm 12.4 \mathrm{~g})$ respectively were noted. Flake ice prepared by the flake ice machine (Castel MAC F80C, Italy) was used to chill the fishes during transportation. Tilapia and common carp were then cleaned with tap water to remove the dust, dirt, sand and undesirable matters. Physical dressing was done to remove the head, entrails and fins. The dressed fish was then thoroughly cleaned in chilled water $\left(2-5^{\circ} \mathrm{C}\right)$ to remove blood and peritoneal membrane. The percentage yield of dressed fish was calculated.

\section{Preparation of Fish Mince}

The dressed fish were put into a mechanical deboner/ mincer (Baader/60, Germany) to separate the fish mince (or minced meat). The fish mince was collected from one side of deboner and the percentage yield was calculated. Low density polyethylene (LDPE) bags were used to pack the fish mince till it was processed to prepare surimi.

\section{Preparation of Surimi}

Fish mince was washed with cold water $\left(5^{\circ} \mathrm{C}\right)$ at a mince/ water ratio of $1: 3(\mathrm{w} / \mathrm{v})$ to prepare surimi. The mixture was agitated gently for $4 \mathrm{~min}$ and then filtered through nylon screen (pore size: $0.2 \mathrm{~mm}$ ). The washing was repeated for three times with the third washing in $\mathrm{NaCl}$ $(0.5 \%)$ solution in cold water $\left(5^{\circ} \mathrm{C}\right)$. And then sucrose $(\mathrm{E}$ 452) (4\%), sorbitol (E 420) (4\%), sodium tripolyphosphate (E 451$)(0.25 \%)$ and sodium chloride $(2.5 \%)$ were added as preservatives into the washed minced meat and mixed well to obtain surimi. The yield of surimi was calculated and then immediately processed to prepare restructured surimi gel product fish paneer.

\section{Preparation of Fish Paneer}

The surimi (containing about $80 \%$ moisture) was chopped into small pieces, and grinded in a mixer. It was then mixed well with additives (table 1) for 5-10 min till it produced a consistent dispersion. The dispersion mixture was then incubated $\left(40{ }^{\circ} \mathrm{C}\right)$ for $30 \mathrm{~min}$ separately in a stainless steel plate for setting the gel. The gel was heated in steam cooker $\left(90^{\circ} \mathrm{C}\right)$ for $45 \mathrm{~min}$ to prepare fish paneer. It was stored in ultra freezer $\left(-20^{\circ} \mathrm{C}\right)$ for further studies. 
Table 1: Additive Used for Preparation of Fish Paneer

\begin{tabular}{ll}
\hline Sample & Surimi Source + Additives \\
\hline T C & Tilapia (no additives, Control) \\
T E & Tilapia + Egg White $(1 \%)$ \\
T T & Tilapia + Transglutaminase $(0.5 \%)$ \\
C C & Common carp (no additives, Control) \\
C E & Common carp + Egg White (1\%) \\
C T & Common carp + Transglutaminase $(0.5 \%)$ \\
& Tilapia (50\%) + Common Carp (50\%) (no \\
& additives, Control) \\
$(\mathrm{T}+\mathrm{C}) \mathrm{E}) \mathrm{T}$ & Whilapia $(50 \%)+$ Common Carp $(50 \%)+$ Egg \\
& Tilapia $(50 \%)+$ Common Carp $(50 \%)+$ \\
$(\mathrm{T}+\mathrm{C}) \mathrm{T}$ & Transglutaminase $(0.5 \%)$ \\
\hline
\end{tabular}

\section{Percentage Yield Analysis}

The yield of tilapia and common carp at different processing stages namely dressed fish, fish mince, surimi and fish paneer $(\mathrm{w} / \mathrm{w})$ were calculated and expressed in percentage.

\section{Gel Strength Analysis}

Universal testing machine (TA-PLUS texture analyzer, Lloyd instruments, UK) was used for the texture analysis. The gel strength of fish paneer was estimated as per the method of Tammatinna et al. (2007). Gels were equilibrated and evaluated at room temperature $\left(28-32{ }^{\circ} \mathrm{C}\right)$. Cylinder shaped samples $(2.5 \mathrm{~cm}$ long) were prepared and subjected to determination. The gel strength (or breaking force) was measured using the texture analyzer equipped with a spherical plunger (diameter $5 \mathrm{~mm}$; depression speed 60 $\mathrm{mm} / \mathrm{min}$ ) and expressed as kilogram force (kgf).

\section{Gel Quality Analysis}

The gel quality of fish paneer was evaluated using a folding test following the method of Lee (1984). A slice ( $3 \mathrm{~mm}$ thick) of fish paneer was folded into four quarters. A gel that could be folded into four without producing any crack was rated as 'AA' quality. An 'A' quality gel could be folded into two without cracking but a crack(s) occur(s) when folded in four. A ' $\mathrm{B}$ ' quality gel produced a minor crack(s) when folded in two. A ' $\mathrm{C}$ ' quality gel spitted into two pieces when folded in two while a ' $\mathrm{D}$ ' quality gel came apart when just pressed with finger. Based on the breaking of the gel due to the folding needed to break or crack, the sample was scored on 1-5 scale; 5 for Class 'AA' (good quality) and 1 for 'D' (poor quality) (table 2).

Table 2: Gel Quality of Fish Paneer in terms of Class/Grade of Folding Test

\begin{tabular}{llll}
\hline \multirow{2}{*}{ Samples } & \multicolumn{3}{c}{ Folding test } \\
\cline { 2 - 4 } & Finger dip & Folding & Class/ Grade \\
\hline TC & No & Yes & Class B/ 3 \\
TE & No & No & Class AA/ 5 \\
TT & No & No & Class AA/ 5 \\
CC & No & Yes & Class B/ 3 \\
CE & No & No & Class AA/ 5 \\
CT & No & No & Class AA/ 5 \\
$(\mathrm{T}+\mathrm{C})$ C & No & Slightly break & Class A/ 4 \\
$(\mathrm{T}+\mathrm{C})$ E & No & No & Class AA/ 5 \\
$(\mathrm{T}+\mathrm{C}) \mathrm{T}$ & No & No & Class AA/ 5 \\
\hline
\end{tabular}

\section{Water Holding Capacity Analysis}

Water holding capacity (WHC) was defined as water (ml) hold by per gram of protein (Miller and Groninger, 1976). The method of Gomez-Guillen and Montero (1996) was followed to measure WHC of fish paneer. Distilled water $(40 \mathrm{ml})$ and sample $(1 \mathrm{~g})$ were taken in a centrifuge tube $(50 \mathrm{ml})$. It was mixed for $5 \mathrm{~min}$ using a vortex mixture. And then the tubes were centrifuged (7500 g; $5 \mathrm{~min})$. The supernatant separated using a funnel was collected into a calibrated beaker $(50 \mathrm{ml})$ and the volume was noted. The volume of supernatant was subtracted from the initial volume (40 ml). The result was calculated using Eq. (1).

$$
\operatorname{WHC}(\%)=\frac{V_{1}-V_{2}}{V_{1}} \times 100
$$

Where, $V_{1}$ was the volume $(\mathrm{ml})$ of distilled water taken before centrifugation and $V_{2}$ was the volume $(\mathrm{ml})$ of supernatant obtained after centrifugation.

\section{Expressible Moisture Content Analysis}

Expressible moisture content (EMC) of fish paneer was determined by the method of Tammatinna et al. (2007). Samples $(0.5 \mathrm{~cm}$ thick) were weighed and placed between 
two pieces of Whatman Filter Paper No. 1 (125 mm diameter) at the top and three pieces of the same filter papers at the bottom. The standard weight $(5 \mathrm{~kg})$ was placed on the top of the sample and maintained for $2 \mathrm{~min}$. The sample was then removed and weighed again. EMC was calculated using Eq. (2).

$$
\operatorname{EMC}(\%)=\frac{X-Y}{X} \times 100
$$

Where, $X$ was the weight $(\mathrm{g})$ of sample before treatment and $\mathrm{Y}$ was the weight $(\mathrm{g})$ of sample after treatment.

\section{Microstructure Analysis}

For the visualization of microstructure of fish paneer, a versatile tungsten thermionic emission scanning electron microscope (SEM) (VEGA 3 TESCAN, Czech Republic) with EDAX (Bruker) facilities was used. This microscope available at Centre for Nanoscience and Nanotechnology, Gandhigram Rural Institute-Deemed University, Gandhigram, India was used to view SEM images of the restructured surimi gel product fish paneer.

\section{Statistical Analysis}

All analyses were done in triplicates and the data were subjected to one-way analysis of variance (ANOVA) using SPSS 10.0 (SPSS Inc., Chicago, IL, USA). Statistical significance difference $(p<0.05)$ was analyzed and the results were expressed or plotted as the mean values \pm standard deviation.

\section{RESULTS AND DISCUSSION}

\section{Yield}

The yield of dressed fish, fish mince, surimi and fish paneer $(w / w)$ of tilapia was more $(p<0.05)$ than common carp (Fig. 1). The dressing yield of fish varied with its size. The percentage of dressed fish obtained from tilapia and common carp were $59.76 \pm 0.86$ and $54.12 \pm 6.45$ respectively. The similar dressing yield was reported in freshwater fish such as silver carp (Hypophthalmichthys molitrix) (59.28\%), tilapia (59.76\%) and common carp $(54.12 \%)$ (Siddaiah, 1994). The yield (\%) of fish mince from dressed tilapia and common carp $(57.06 \pm 5.98$ and
$53.23 \pm 3.75)$ was higher than that of raw tilapia and common carp $(34.10 \pm 3.45$ and $32.73 \pm 3.97)$. Sankar, (2000) reported that the yield of mince from black rohu (Labeo calbasu) slightly higher than major carps (30$35 \%$ ). Similar values were found in the present study. Gleman and Benjamin (1989) reported $41-45 \%$ yield of fish mince from silver carp. This was slightly higher than that obtained in the present study. Venugopal et al. (2009) reported the influence of method of processing and the machine used for picking meat on the yield of fish mince. The percentage of surimi obtained from mince $(66.06 \pm$ 9.06 and $59.44 \pm 1.38 \%$ ), dressed ( $36.54 \pm 1.84$ and 36.48 $\pm 3.75 \%)$ and raw $(21.84 \pm 1.15$ and $19.97 \pm 2.79 \%)$ tilapia and common carp respectively were close to the results of other study. The surimi prepared from fish mince after repeated washing resulted in a loss of $34 \%$ of the fish mince for tilapia and $41 \%$ for common carp. Therefore, the average yield of surimi acquired from tilapia and common carp was around $22 \%$ and $20 \%$ respectively, in terms of whole weight. Yathavamoorthi et al. (2010) reported that the yield of surimi from black rohu was around 31\%. Finally, the yield (\%) of fish paneer obtained from the raw tilapia and common carp were $20.5 \pm 0.6$ and $19.0 \pm 0.55$ respectively. The tilapia fish in our study was smaller (28 $\mathrm{cm})$ than common carp $(50 \mathrm{~cm})$ but the yield obtained was higher in tilapia. This may be due to high gonad portion (ovary) removed from the common carp.

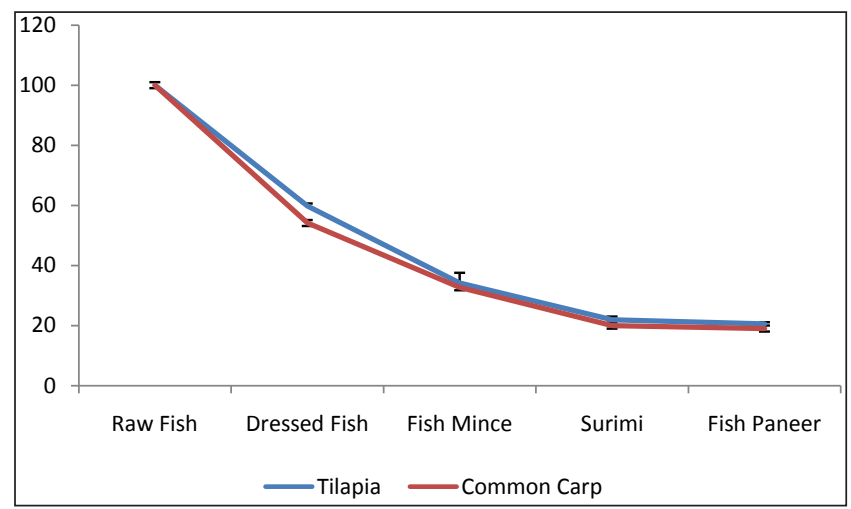

Fig. 1: Percentage yield of tilapia and common carp at different processing stages. Each data point is the average of triplicate samples. Bars indicate the standard deviation

\section{Gel strength}

The gel strength is the textural characteristics of surimi or restructured surimi gel product like fish paneer. The 
gel strength of Fish Paneer (Fig. 2) prepared with the equal proportion of tilapia and common carp surimi with transglutaminase $(0.5 \%)(23.7 \mathrm{kgf})$ was highest $(p<0.05)$ of all other fish paneer prepared. This result suggested the induction of cross linking of adjacent myofibrillar proteins during incubation by transglutaminase as reported by Uresti et al. (2006). Tellez-Luis et al. (2002) found the similar result in silver carp (Hypophthalmichthys molitrix). The surimi added with egg white had higher gel strength than that of control but lower compared to that of transglutaminase. This suggested the role of egg white in positively improving the gel strength but had lesser efficiency than transglutaminase. Lee et al. (1992) and Park (2000) reported the use of protein additives such as egg white for increasing the gel strength and whiter and glossier appearance to the gel. Egg white is reported to improve mechanical and functional properties of fish products (Yetim and Ockerman, 1995). Low gel strength was found in common carp compared to tilapia and mixture of both. This indicates a better gel strength property of tilapia which is even maintained in the mixture of fish surimi from both the fishes.

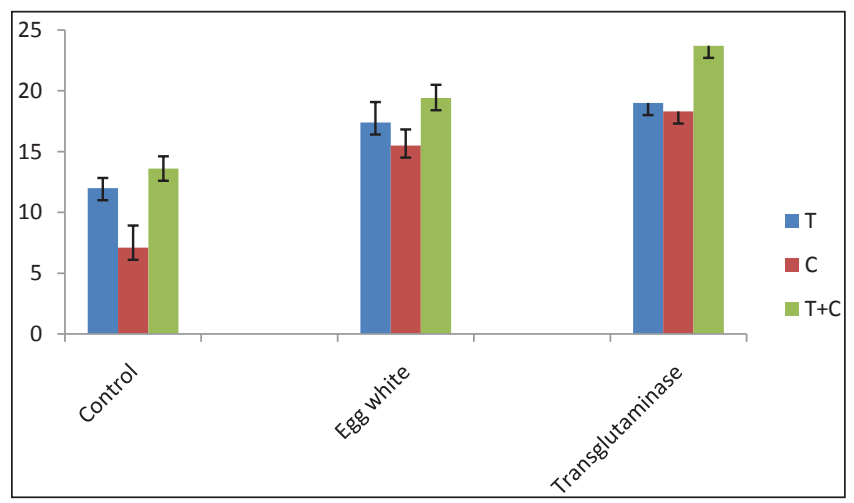

Fig. 2: Gel strength of fish paneer obtained with egg white (1\%) and transglutaminase $(0.5 \%)$ from tilapia $(\mathrm{T})$, common carp $(\mathrm{C})$ and both $(\mathrm{T}+\mathrm{C}, 1: 1)$. Each data point is the average of triplicate samples. Bars indicate the standard deviation

\section{Gel quality}

Different class/grade of folding test was used to study the gel quality of fish paneer by observing the breaks while folding it. None of the products broke while folding test was carried out using finger dip but multiple folding arrived with variations among fish paneer. A slight break was observed when folding of the product prepared with equal proportion of tilapia and common carp surimi. Fish paneer prepared with the combination of egg white and transglutaminase showed no break while folding. Folding test is a tool to differentiate between high quality and low quality surimi gels (Thanachan, 2008).

\section{Water holding capacity}

The water holding capacity (WHC) of fish paneer (Fig. $3)$ was found higher $(p<0.05)$ for those with higher gel strength. Similar result has been reported by Thanachan (2008). Fish paneer prepared with the equal proportion of tilapia and common carp surimi with transglutaminase which showed the highest gel strength $(23.7 \mathrm{kgf})$ also showed the highest water holding capacity (142\%). Uresti et al. (2006) reported the cross linking of adjacent myofibrillar proteins by transglutaminase during incubation and this may assist in the protein cross linking between tilapia and common carp surimi and thereby help in the retention of water in the gel matrix. This study also found the higher WHC (135\%) of the product prepared with the equal proportion of tilapia and common carp surimi with egg white. Egg white helps in the retention of water by the surimi gel matrix. The binding of water to the proteins is mainly related to the polar hydrophilic groups (Kinsella, 1982).

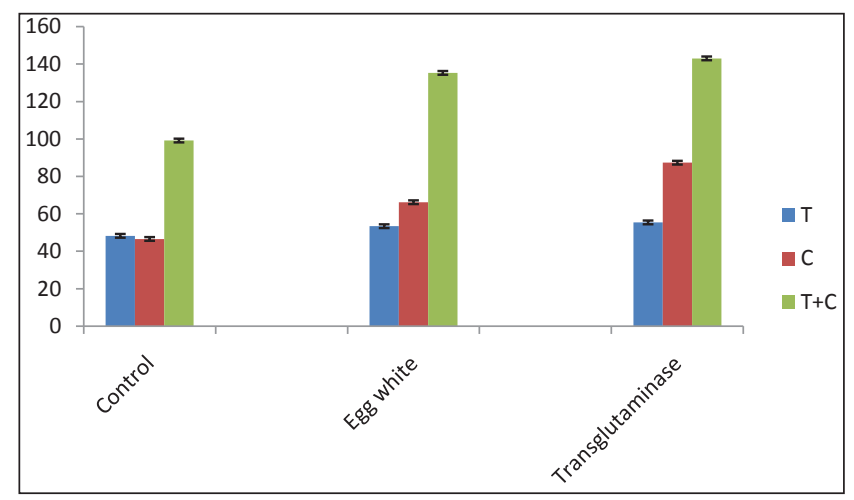

Fig. 3: Water holding capacity of fish paneer obtained with egg white $(1 \%)$ and transglutaminase $(0.5 \%)$ from tilapia $(\mathrm{T})$, common carp $(\mathrm{C})$ and both $(\mathrm{T}+\mathrm{C}, 1: 1)$. Each data point is the average of triplicate samples. Bars indicate the standard deviation

\section{Expressible moisture content}

Unlike WHC, the expressible moisture content of fish 
paneer (Fig. 4) was low. Low EMC of gels suggested the more water retention in the gel network (Niwa, 1992; Rawdkuen et al., 2009). The stronger gel network was possibly associated with the capacity of holding the water (Tammatinna et al., 2007).

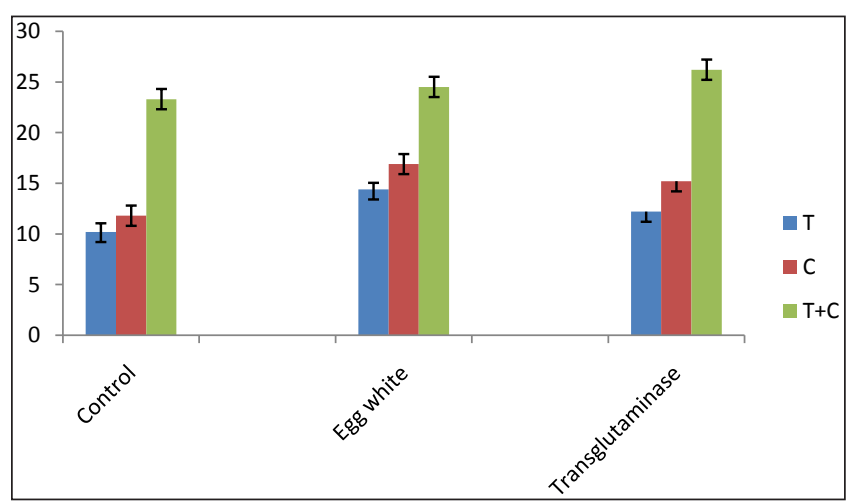

Fig. 4: Expressible moisture content of fish paneer obtained with egg white $(1 \%)$ and transglutaminase $(0.5 \%)$ from tilapia $(\mathrm{T})$, common carp $(\mathrm{C})$ and both $(\mathrm{T}+\mathrm{C}, 1: 1)$. Each data point is the average of triplicate samples. Bars indicate the standard deviation

\section{Microstructure of fish paneer}

Microstructure of fish paneer was studied using SEM images (or electron micrograph). The electron micrograph of fish paneer was obtained at 250X, 500X, and 1000X (Fig. 5) and 2500X, 5000X, and 10000X (Fig. 6) magnification. Fish paneer, $(\mathrm{T}+\mathrm{C}) \mathrm{T}$ prepared with the equal proportion of tilapia and common carp surimi with transglutaminase $(0.5 \%)$ exhibited the smooth surface with cavities at $250 \mathrm{X}$ magnification, the uniform exterior with small holes at 500X magnification and no holes but small projections at $1000 \mathrm{X}$ magnification. Magnification of fish paneer at $2500 \mathrm{X}$ showed tight aggregation of different protein molecules with each other with small gaps here and there. At 5000X magnification, large voids with even arrangement of protein molecules were seen. At 10000X magnification, the image showed even smooth arrangement between different protein molecules. The protein molecules were bonded very tightly with each other.

In fish paner, $(\mathrm{T}+\mathrm{C})$ E prepared with the equal proportion of tilapia and common carp surimi with egg white (1\%), the outer portion was observed smooth with fewer vacuities at
250X magnification, the outside portion views stable but uneven with small out thrusts at 500X magnification and the similar image characteristics as in 500X magnification (patchy superficial portion with little protrusions) at 1000X magnification. At 2500X magnification, the protein molecules arranged closely but with crumbles on the surface. At 5000X magnification, the protein molecules were visible clearly and they were unevenly bonded with each other showing eaves and gaps in between molecules. At $10000 \mathrm{X}$ magnification, the picture was not clear and showing molecular arrangements with gaps.

Fish paneer, $(\mathrm{T}+\mathrm{C}) \mathrm{C}$ showed uneven surface with large cavities at $250 \mathrm{X}$ magnification, small projections and small voids at 500X magnification and more voids with small prolongation on the exterior portion at $1000 \mathrm{X}$ magnification. At $2500 \mathrm{X}$ magnification, the aggregation of protein molecules was clearly visible. Different protein molecules are intimately arranged but with small gaps here and there. At 5000X magnification, the protein molecules formed tight position but the overall surface views were unreliable. At 10000X magnification, even clearer picture displayed the molecule pinpoint and the aggregation of the protein molecules were even and noticed smooth. From these microstructures, it can be concluded that transglutaminase can bind the different protein molecules effectively than egg white.

Rawdkuen et al. (2009) found a smooth protein gel matrix with numerous small holes, which formed a porous network structure in the microstructure of tilapia surimi gels. Our study showed the similar results (small holes) in the microstructures of fish paneer. Surimi gel network became finer with the addition of transglutaminase as compared with the control gel (without transglutaminase). Our study reported somewhat smooth appearance of fish paneer prepared with the equal proportion of tilapia and common carp surimi. Myofibrillar proteins could undergo the aggregation more effectively in the presence of transglutaminase (Benjakul et al. 2008). A more compact and denser gel network was developed due to the higher breaking force and deformation and the lowered expressible moisture content when trasnglutaminase was added in surimi (Kaewudom et al., 2012).

Moreno et al. (2013) observed that sample with transglutaminase exhibited a more reticulated network matrix than that of sample with alginate, which was 


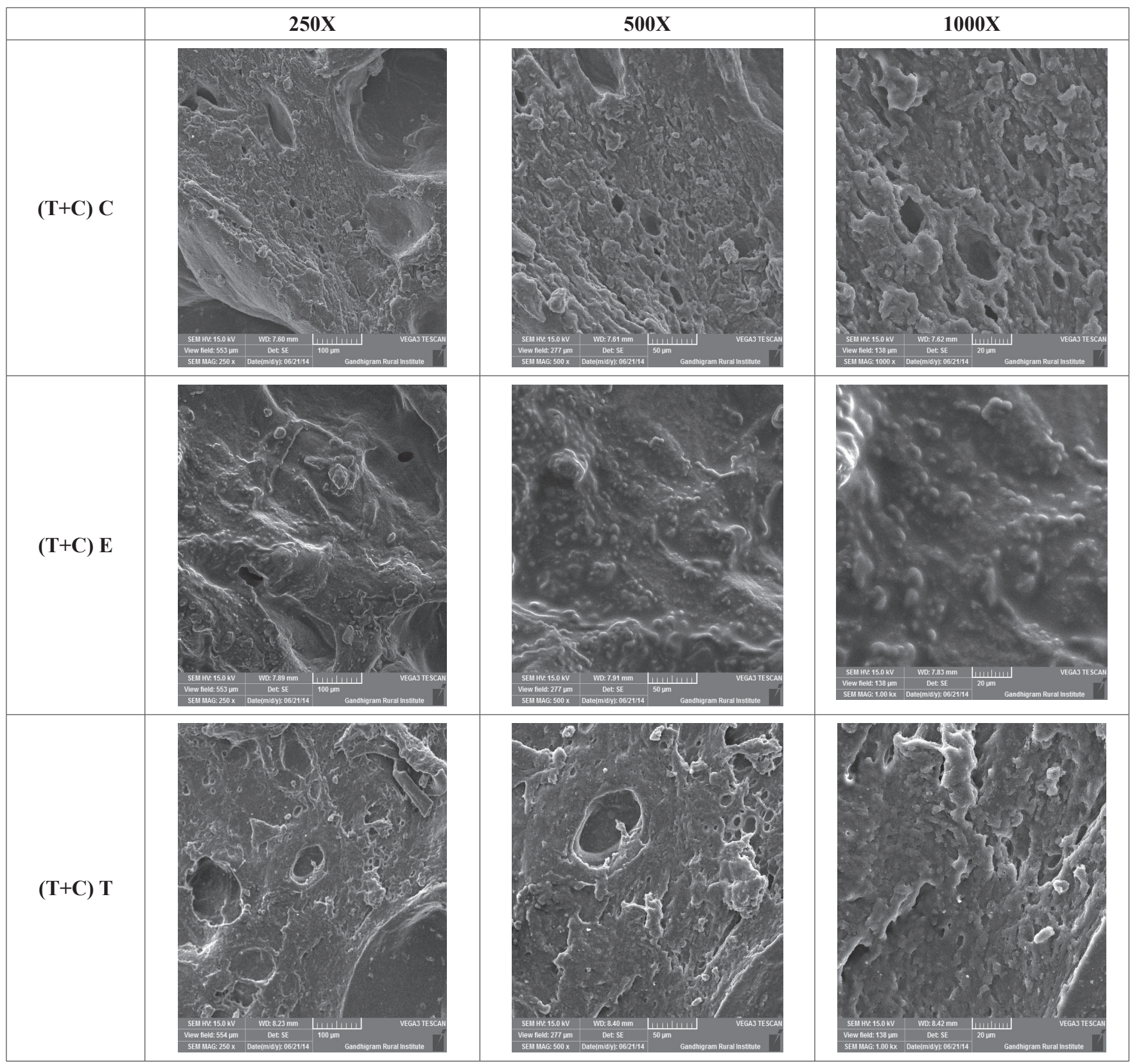

Fig. 5: Microstructure of fish paneer obtained from tilapia $(\mathrm{T})$ and common carp $(\mathrm{C})$ both $(\mathrm{T}+\mathrm{C}, 1: 1)$ with egg white $(1 \%)$ and transglutaminase $(0.5 \%)$ seen in SEM images at $250 \mathrm{X}, 500 \mathrm{X}$, and $1000 \mathrm{X}$ magnification. $(\mathrm{T}+\mathrm{C}) \mathrm{C}$ : surimi (tilapia: $50 \%+$ common carp 50\%) + no additives (control), $(\mathrm{T}+\mathrm{C}) \mathrm{E}$ : surimi (tilapia: $50 \%+$ common carp 50\%) + egg white $(1 \%)(\mathrm{T}+\mathrm{C}) \mathrm{T}$ : surimi (tilapia: $50 \%+$ common carp 50\%) + transglutaminase $(0.5 \%)$

consistent with the higher protein aggregation observed in the sample made with transglutaminase. These results was in agreement with those found by Montero et al. (2000) and Perez-Mateos et al. (2002), who reported that the alginate network was connected in some way (normally electrostatic interactions) with muscular protein net.
Transglutaminase was postulated to build up the network structure through intermolecular lysine cross-linking in cooperation with protein aggregation via hydrophobic interaction, disulfide bonds and other interaction during heating process (Benjakul et al., 2001). 


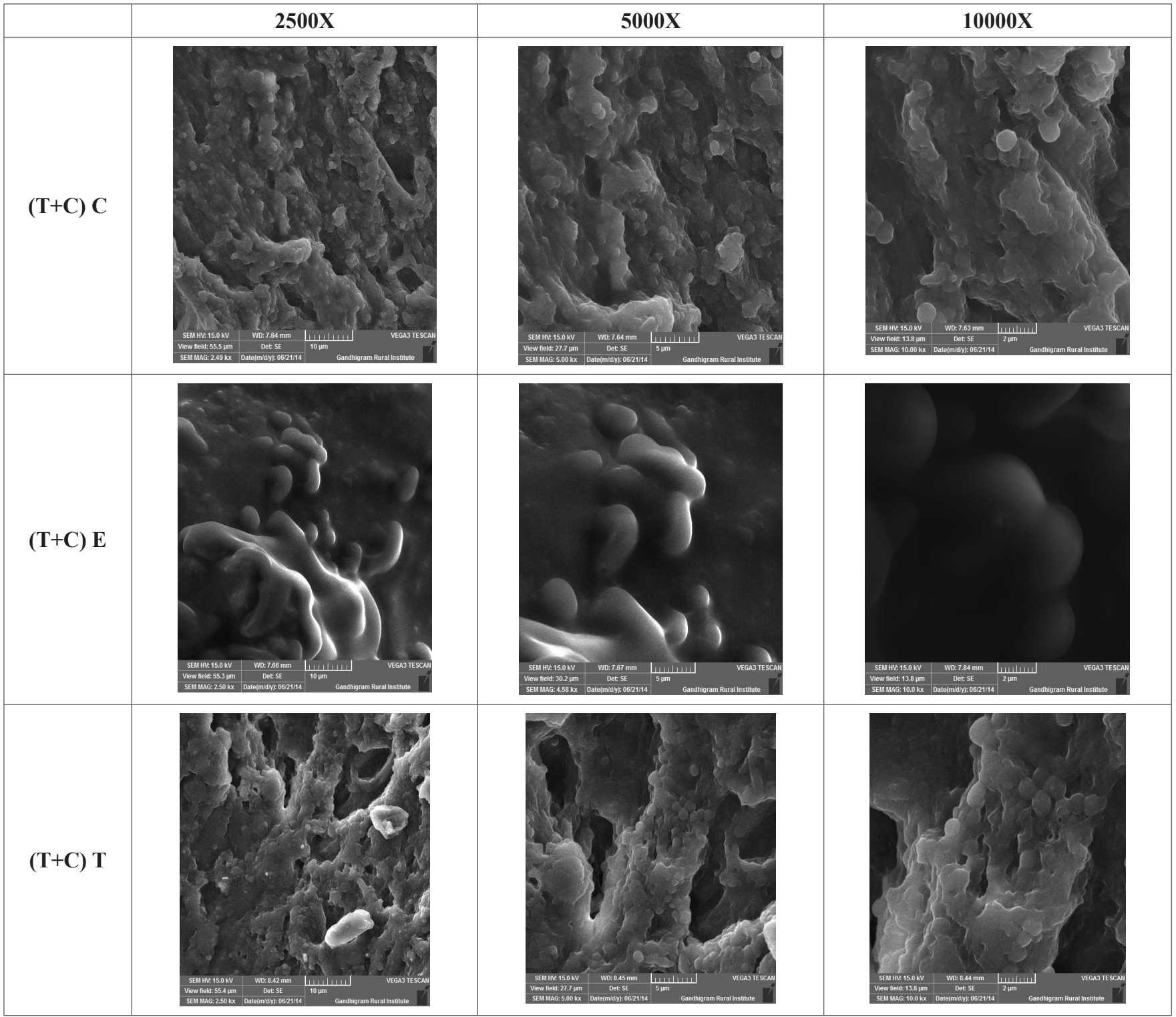

Fig. 6: Microstructure of fish paneer obtained from tilapia $(\mathrm{T})$ and common carp $(\mathrm{C})$ both $(\mathrm{T}+\mathrm{C}, 1: 1)$ with egg white $(1 \%)$ and transglutaminase $(0.5 \%)$ seen in SEM images at $2500 \mathrm{X}, 5000 \mathrm{X}$, and $10000 \mathrm{X}$ magnification. $(\mathrm{T}+\mathrm{C}) \mathrm{C}$ : surimi (tilapia: $50 \%+$ common carp 50\%) + no additives (control), $(\mathrm{T}+\mathrm{C}) \mathrm{E}$ : surimi (tilapia: 50\% + common carp 50\%) + egg white $(1 \%)(\mathrm{T}+\mathrm{C}) \mathrm{T}$ : surimi (tilapia: $50 \%+$ common carp 50\%) + transglutaminase $(0.5 \%)$

Arfat and Benjakul (2012) reported the microstructures of surimi gels prepared by heating at different conditions. Kamaboko gels with setting at $40{ }^{\circ} \mathrm{C}$ showed the higher interconnected three-dimensional protein networks. More compact and denser gel network with finer strand observed in that sample was coincidental with the higher breaking force and higher water holding capacity. In the present study the setting temperature was $40^{\circ} \mathrm{C}$. Setting temperature in combination with transglutaminase addition could improve the gel-forming ability of gel by rendering the more ordered fibrillar structure (Tammatinna et al., 2007). Suwari gels with $2.5 \%$ and $1.5 \% \mathrm{NaCl}$ was observed by Gomez-Guillen et al. (1997) and found that the appearance of the matrices was more irregular in gels made with the lower salt concentration than with the higher salt concentration and the muscle protein appeared 
much more compact, which caused the formation of large cracks and cavities of uneven size. With the higher salt concentration, there is more extensive solubilization of myofibrillar proteins, thus favouring the monomer form of myosin (Burgarella et al., 1985). The concentration of $\mathrm{NaCl}$ used in the present study was $2.5 \%$.

\section{CONCLUSION}

A high value restructured surimi gel product fish paneer was developed from low value fishes like tilapia (Oreochromis $s p$ ) and common carp (Cyprinus carpio) and the effects of transglutaminase and egg white on its functional properties and microstructure were studied. Highest gel strength (23.7 $\mathrm{kgf})$, WHC (142\%) and EMC (26\%) were found in fish paneer prepared with transglutaminase $(0.5 \%)$ added in surimi from tilapia and common carp (each 50\%). Folding test found the highest quality of gel in fish paneer prepared from surimi containing transglutaminase. The egg white (1\%) influenced the functional qualities positively with lesser effect than transglutaminase. The scanning electron microscopy (SEM) images of fish paneer exhibited the better effectiveness of transglutaminase $(0.05 \%)$ in binding the protein molecules than egg white (1\%).

\section{ACKNOWLEDGEMENTS}

First author acknowledges FC\&RI, Thoothukudi for providing the facilities to carry out this work.

\section{REFERENCES}

Arfat, Y.A. and Benjakul, S. 2012. Gelling characteristics of surimi from yellow stripe trevally (Selaroides leptolepis). Int. Aquatic Res. 4: 1-13.

Benjakul, S., Phatcharat, S., Tammatinna, A., Visessanguan, W. and Kishimura, H. 2008. Improvement of gelling properties of lizardfish mince as influenced by microbial transglutaminase and fish freshness. J. Food Sci., 73: 239-246.

Benjakul, S., Visessanguan, W. and Srivilai, C. 2001. Gel properties of bigeye snapper (Priacanthus tayenus) surimi as affected by setting and porcine plasma protein. J. Food Qual., 24: 453-471.

Burgarella, J.C., Lanier, T.C., Hamann, D.D. and Wu, M.C. 1985. Gel strength development during heating of surimi in combination with egg white or whey protein concentrate. $J$. Food Sci., 50: 1595-1597.
NFP. 2020. National Fisheries Policy 2020 of Government of India (draft). (http://nfdb.gov.in/PDF/National_Fisheries Policy_2020.pdf; 21 May, 2020).

FAO. 2020. The state of world fisheries and aquaculture 2020-Meeting the sustainable development goals. Rome.

Gleman, A. and Benjamin, E. 1989. Characteristics of mince from pond breed silver carp (Hypopthalmichthys molitrix) and preliminary experiment on its uses in sausages. J. Sci. Food Agric., 47: 225-241.

Gomez-Guillen, M.C. and Montero, P. 1996. Addition of hydrocolloids and non-muscle proteins to sardine (Sardina pilchardus) mince gels-Effect of salt concentration. J. Food Chem., 56(4): 421- 427.

Gomez-Guillen, C., Solas, T. and Montero, P. 1997. Influence of added salt and non-muscle proteins on the rheology and ultrastructure of gels made from minced flesh of sardine (Sardina pilchardus). J. Food Chem., 58(3): 193-202.

Gopakumar, K .1997. Tropical fishery product. Oxford and IBH Publishing Co. Ltd. New Delhi.

Kaewudom, P., Benjakul, S. and Kijroongrojana, K. 2012. Effect of bovine and fish gelatin in combination with microbial transglutaminase on gel properties of threadfin bream surimi. Inter. Aquatic. Res., 4(12): 1-13.

Karmas, E. and Lauber E. 1987. Novel products from underutilized fish using combined processing technology. $J$. Food Sci., 52: 7-9.

Kinsella, J.E. 1982. Relationship between structure and functional properties of food proteins. In: Fox, P.F. and Cowdon, J.J. (Eds.) Food Proteins. Applied Science Publishers, London, pp. 1-51.

Kuraishi, C., Yamazaki, K. and Susa, Y. 2001. Transglutaminase: its utilization in the food industry. Food Rev. Int., 17(2): 221246 .

Miller, R. and Groninger, H.S.1976. Functional properties of enzyme modified acylated fish protein derivates. J. Food Sci., 41: 268-272.

Montero, P., Hurtado, J.L. and Perez-Mateos, M. 2000. Microstructural behaviour and gelling characteristics of myosystem protein gels interacting with hydrocolloids. Food Hydrocolloids, 14(5): 455-461.

Moreno, H., Carballo, J. and Borderias, J. 2013. Raw-appearing restructured fish models made with sodium alginate or microbial transglutaminase and effect of chilled storage. $J$. Food Sci. and Tech., 33(1): 137-145.

MPEDA. 2020. India's seafood exports pegged at 12,89,651 MT in FY 2019-20. https://mpeda.gov.in/MPEDA/admin/files/ PressRelease/MPEDA ExportPerformance.pdf; accessed on 12.10.2020. 
Niwa, E. 1992. Chemistry of surimi gelation. In: Lanier, T.C. and Lee, C.M. (Eds.) Surimi Technology. Marcel Dekker, New York, pp. 389-428.

Park, J.W. and Morrissey, M.T. 2000. Manufacturing of surimi from light muscle fish. In: Park, J.W. (Ed.) Surimi and surimi seafood, CRC Press, Boca Raton, pp. 23-58.

Park, J.W. 2014. Ingredient technology for Surimi and Surimi Seafood. In: Park, J.W. (Ed.) Surimi and surimi seafood. CRC Press. 18: 453-496.

Perez-Mateos, M., Solas, T. and Montero, P. 2002. Carrageenans and alginate effect on properties of combines pressure and temperature in fish mince gels. Food Hydrocolloids, 16: 225233.

Ramirez, J.A., Alfredo, D.A., Gonzalo, V. and Manuel, V. 2006. Production of low salt restructured fish products from Mexican flounder (Cyclopsetta chittendeni) using microbial transglutaminase or whey protein concentrate as binders. Eur. Food Res. Tech., 223: 341-345.

Rawdkuen, S., Sai-Ut, S., Khamsorn, S., Chaijan, M. and Benjakul S. 2009. Biochemical and gelling properties of tilapia surimi and protein recovered using an acid-alkaline process. J. Food Chem., 112: 112-119.

Sankar, T.V. 2000. Biochemical and storage characteristics of myofibrillar protein (surimi) from freshwater major carps. Ph.D. Thesis. Cochin University of Science and Technology, Cochin, India.

Siddaiah, D. 1994. Stability of minced meat of fresh water fish silver carp (Hypophthalmichthys molitrix) at lower temperature and its suitability to prepare paste products. M.F.Sc. Thesis. University of Agricultural Sciences, Bangalore, Karnataka, pp. 42-95.
Tammatinna, A. Bengakul, S., Visessanguan, W. and Tanaka M. 2007. Gelling properties of white shrimp meat as influenced by setting condition and microbial transglutaminase. $J$ Food Sci., 40: 1489-1497.

Tellez-Luis, S.J., Uresti, R.M., Ramirez, J.A. and Vazquez, M. 2002. Low-salt restructured fish products using microbial transglutaminase as binding agent. J. Sci. Food Agric., 82: 953-959.

Thanachan, M. 2008. Preparation and properties of surimi gels from tilapia and red tilapia. Naresuan Univ. J., 16(2): 105111 .

Uresti, R.M., Velazquez, G., Vazquez, M., Ramirez, J.A. and Torres, J.A. 2006. Effects of combining microbial transglutaminase and high pressure processing treatments on mechanical properties of heat-induced gels prepared from arrowtooth flounder (Atheresthes stomias). J. Food Chem., 94: 202-209.

Venugopal, V., Shahidi, F. and Tung-Ching, L. 2009. Value added products from underutilized fish species. CRC. Crit. Rev. Food Sci. Nutri., 35(5): 431-435.

Worawan, P., Chaijan, M. and Benjakul, S. 2010. Gel properties of croaker-mackerel surimi blend. J. Food Chem., 122: 11221128.

Yathavamoorthi, R., Sankar, T.V. and Ravishankar, C.N. 2010. Effect of ice storage and washing on the Protein constituents and textural properties of surimi from Labeo Calbasu (Hamilton, 1882). Indian J. Fish., 57(4): 85-91.

Yetim, H. and Ockerman, W. 1995. The effects of egg white, tumbling and storage time on proximate composition and protein fractions of restructured fish product. J. Aquatic Food Product Tech., 4: 65-77. 